\title{
Analisa Implementasi Metode Fuzzy Time Series Jasim pada Prediksi Perkembangan COVID-19 di Indonesia
}

\author{
Dedy Rahman Prehanto ${ }^{1}$, Ginanjar Setyo Permadi ${ }^{2}$, Melvin Nurdiansari $^{3^{*}}$ \\ ${ }^{1}$ Program Studi Teknik Informatika, Fakultas Teknik, Universitas Negeri Surabaya, Surabaya \\ ${ }^{2}$ Program Studi D3 Manajemen Informatika, Fakultas Tekonologi Informasi, Universitas Hasyim Asy'ari, Jombang \\ ${ }^{3}$ Program Studi Sistem Informasi, Fakultas Tekonologi Informasi, Universitas Hasyim Asy’ari, Jombang
}

Naskah Diterima : 24 September 2020; Diterima Publikasi : 15 September 2021

DOI: $10.21456 /$ vol11iss2pp125-130

\begin{abstract}
The pandemic of COVID-19 that has been going on since March 2020 until now has weakened many sectors in many countries an Indonesia as well. In Indonesia, more than 9,000 people have died because of this pandemic. In the first week, 56 cases of COVID-19 were recorded and the cases continued to increase to more than 2,000 cases per week so that the increasing number of cases could result in a lack of service provision and facilities for medical. This study aims to determine the forecasting scheme and how the development of COVID-19 cases that occur in Indonesia. Fuzzy Time Series Jasim method that is applied to find out how to do forecasts by managing previous data. This method uses the determination of the width of the interval, the formation of a set from historical data and using of the average based length method. In this method also used grouping and data relations that have been fuzzified. From the method that has been used, it can be seen that the results obtained from the Fuzzy Time Series Jasim method are obtained from the accuracy rate of the accuracy error using MAD of 286. And the error magnitude of the forecasting results with the actual data using MAPE is $2.43 \%$. Where it can be concluded that the use of Fuzzy Time Series Jasim method in this study provides good forecasting results.
\end{abstract}

Keywords: COVID-19; Fuzzy Time Series Jasim; Forecasting

\begin{abstract}
Abstrak
Pandemi COVID-19 yang telah berlangsung sejak bulan Maret 2020 hingga sekarang yang telah melemahkan banyak sektor di banyak negara termasuk Indonesia. Di Indonesia sendiri sudah tercatat lebih dari 9.000 warga yang meninggal akibat pandemi ini. Pada minggu pertama tercatat 56 kasus COVID-19 dan terus bertambah hingga lebih dari 2.000 kasus perminggu sehingga dengan terus bertambahnya kasus dapat mengakibatkan kurangnya penyediaan layanan, dan fasilitas tenaga medis. Penelitian ini bertujuan untuk mengetahui skema peramalan dan bagaimana perkembangan kasus COVID-19 yang terjadi di Indonesia. Metode Fuzzy Time Series Jasim merupakan metode yang diterapkan guna mengetahui bagaimana dilakukannya peramalan dengan mengelolah data sebelumnya. Metode ini menggunakan penentuan lebar interval, pembentukan himpunan dari data historis dan penggunaan metode average based length. Pada metode ini digunakan juga pengelompokan dan relasi data yang telah difuzzifikasi. Dari metode yang telah digunakan dapat diketahui hasil yang diperoleh dari metode Fuzzy Time Series Jasim yaitu didapatkan tingkat akurasi dari besar kesalahan akurasi menggunakan MAD sebesar 286. Dan besar eror pada hasil peramalan dengan data aktual yang telah ada menggunakan MAPE sebesar 2.43\%. Dimana didapatkan kesimpulan bahwa penggunaan Fuzzy Time Series Jasim pada penelitian ini menyajikan hasil peramalan dengan baik.
\end{abstract}

Kata Kunci: COVID-19; Fuzzy Time Series Jasim; Prediksi

\section{Pendahuluan}

Tahun 2020 menjadi tahun yang tidak mudah bagi seluruh umat manusia dengan banyaknya kejadian dan kasus yang menimpa. Salah satunya adalah mewabahnya jenis virus baru ya itu Corona Virus Disaese 2019 atau yang biasa kita sebut COVID-19. Virus yang ditemukan dengan kasus pertama di kota wuhan pada akhir tahun 2019 ini telah menjadi pandemi hampir seluruh negara dan melemahkan banyak sektor tidak terkecuali Indonesia. Setelah

*) Penulis korespondensi: melvinnurdiansari@gmail.com menjadi perbincangan seluruh negara sejak awal terdeteksi, tepat pada tanggal 2 Maret 2020, presiden Jokowi mengumumkan pertama kalinya ditemukannya pasien dengan kasus COVID-19 di Indonesia. Dan terhitung sejak 12 Maret 2020, organisasi yang menangangani tentang kesehatan dunia atau World Health Organization (WHO) menetapkan kasus dengan terjangkitnya virus jenis baru ini sebagai Pandemi Global dan menegaskan seluruh pemerintahan untuk melakukan penanganan tegas dimasing masing negaranya. 
Sejak kasus pertama dan kedua terjadi, dalam seminggu kasus COVID-19 di indonesia mengalami peningkatan dan semakin meluas, tercatat di minggu pertama ditemukannya 56 kasus COVID-19 dengan 6 kasus positif di indonesia. Hingga saat ini, pada bulan agustus 2020 tercatat lebih dari 160.000 kasus COVID-19 di Indonesia. Bahkan, walaupun dengan 160.000 kasus yang tercatat, indonesia masih belum dianggap mencapai puncak pandemi COVID-19 karena angka kasus yang terus bertumbuh dan tidak adanya penurunan secara signifikan. Berdasarkan data dari Our World in Data per agustus 2020, total kasus per sejuta penduduk indonesia adalah sebesar 606,481 dengan rata rata 112,473 kasus baru perminggu.

Beberapa penelitian telah dilakukan, salah satunya adalah menggambarkan pandemi COVID-19 dengan beberapa metode, seperti dalam jurnal Simulasi Berbasis Model Pertumbuhan Parametrik (Pratikto, 2020) dan prediksi akibat dari pandemi COVID-19 seperti yang dilakukan (Fahri dan Jalil, 2019) dalam jurnal Meningkatnya Angka Pengangguran ditengah Pandemi.

Berawal dari terus terjadinya penambahan kasus baru setiap harinya. Dan tidak dapat diperkirakan jumlahnya sehingga dapat menyebabkan penanganan seperti penyediaan layanan, fasilitas, dan tenaga medis yang juga tidak dapat diprediksi. Dari kasus tersebut, maka peneliti melakukan penelitian ini dengan judul "Analisa Implementasi Metode Fuzzy Time Series Jasim pada Prediksi Perkembangan COVID-19 di Indonesia" dengan tujuan untuk mengetahui seberapa efektif penggunaan metode ini pada objek penelitian. Penggunaan metode Fuzzy Time Series Jasim dipilih karena pada penelitian terdahulu metode ini memiliki hasil eror terkecil dibandingkan dengan metode lain.

\section{Kerangka Teori}

\subsection{Pandemi COVID-19}

Penyebaran penyakit atau wabah yang sedang terjadi dapat sangat merugikan bagi banyak pihak, tidak terkecuali pemerintahan yang akan kewalahan dalam mempersiapkan penanganan dari segi perekonomian maupun tenaga kesehatan. Banyak faktor yang dapat mempenggaruhi penyebaran suatu penyakit seperti pandemi yang tengah terjadi saat ini.

Pandemi merupakan penyebaran penyakit yang menyebar bukan hanya pada suatu negara namun juga ke seluruh dunia (Winarno, 2020). Penyebaran yang menjangkit hampir seluruh dunia ini bukan hanya menjadi masalah sepele bagi pemerintahan masing masing negara maupun organisasi kesehatan tingkat dunia. Karena dengan adanya pandemi dapat menyebabkan banyak akibat dan dapat berdampak buruk bagi beberapa aspek.

Hingga saat ini, pemerintah Indonesia belum menemukan vaksin atau obat paten yang mampu mencegah penyebaran ataupun menyembuhkan pasien yang terjangkit. Sudah banyak upaya pemerintah dalam mengakhiri pandemi COVID-19 ini mulai dari penerapan pembatasan sosial skala besar (PSBB), lockdown per daerah hingga new normal yang telah diterapkan untuk menyelamatkan sektor perekonomian. namun sangat disayangkan walaupun sudah menerapkan beberapa kebijakan, pemerintah belum bisa menekan jumlah kasus yang terus bertambah setiap harinya dan belum dapat dipastikan kapan pandemi ini akan berakhir.

\subsection{Metode Peramalan (Forecasting)}

Peramalan atau prediksi (forecasting) adalah msalah yang sering ditemui dalam banyak aspek baik pada peramalan cuaca, iklim, finansial, ekonomi, pergeseran harga saham dan lain sebagainya (Windarti et al., 2020). Metode ini sering digunakan pada bidang industri untuk peramalan produksi atau jumlah perkembangan usaha di masa depan. Hasil dari metode ini dapat digunakan sebagai alat analisis perkiraan atau peramalan dengan perhitungan statistik.

Prediksi memerlukan adanya jenjang durasi (Sucipto dan Syaharuddin, 2018). Dalam penentuan tindakan sangat diperlukan sebuah prediksi begitu juga dengan penyelesaian waktu dan bilamana sesuatu akan terjadi. Sehingga dengan adanya prediksi akan membantu berbagai pihak dalam menyediakan penanganan atau persiapan tidakan yang perlu dilakukan. Pola atau data terdahulu akan diketahui dengan dilakukannya pendekatan analisa yang dilakukan dengan metode peramalan. Sehingga dengan diketahuinya pola tersebut dapat membantu memberikan cara berpikir, bekerja dan memecahkan sebuah masalah secara sistematis (Sudarsono, 2016).

Masalah prediksi sering diklasifikasikan dengan masa waktu pendek, masa waktu menengah, dan juga masa waktu yang panjang (Montgomery et al., 2016). Peramalan jangka pendek biasanya diperlukan untuk hasil perencanaan dalam jangka waktu satu minggu atau kurang dari 5 bulan. Jangka menengah digunakan untuk hasil perencanaan dala jangka waktu lebih dari lima 5 bulan hingga 1 tahun kedepan. Untuk jangka panjang digunakan untuk hasil peramalan beberapa tahun kedepan, biasanya peramalan jangka panjang ini digunakan untuk penentuan masalah seperti pembuatan rencana strategis, sedangkan jangka pendek dan juga menengah biasanya berdasarkan pada identifikasi, model dan penentuan yang ditemukan dalam data terdahulu, karena biasanya data pada peramalan jangka pendek dan menangah menunjukkan data yang tidak berubah secara drastis atau secara cepat, pada peramalan jangka pendek dan menengah ini menggunakan metode statistik dalam pengolahan.

Alasan mengapa peramalan bisa sangat penting adalah karena prediksi pada masa depan dapat menjadi masukan penting dalam banyak jenis proses seperti perencanaan dan pengambilan keputusan dalam berbagai bidang (Montgomery et al., 2016). 


\section{a. Data Time Series}

Data deret waktu atau Data time series adalah sekumpulan data pengamatan, masing masing data dicatat pada waktu tertentu, waktu pengamatan dilakukan pada interval waktu tetap atau dapat dilakukan secara kontinu atau direkam selama beberapa interval waktu (Brockwell, dan Davis, 2002). Salah satu contoh data yang dapat digunakan untuk dilakukannya peramalan adalah data yang diperoleh dari data harian, mingguan, atau bulanan yang disajikan secara berurutan dan runtut.

Penggunaan metode forecasting biasanya didasarkan pada data atau pengamatan variabel yang diamati. Data tersebut biasanya disajikan dalam bentuk time series (Montgomery et al., 2016). Penggunaan data time series untuk peramalan atau forecasting didasarkan karena pada data yang tercatat dalam periode waktu dapat diasumsikan dipengaruhi oleh nilai pada periode waktu sebelumnya. Sehingga, analisa dengan menggunakan data time series memungkinkan untuk dilakukannya peramalan atau forecasting pada masa mendatang. Peramalan menggunakan data time series juga dapat berguna dalam kepentingan berbagai pihak, seperti memprediksi dan menentukan suatu kebijakan tertentu yang sangat dipengaruhi oleh data masa lalu dan hasil peramalan yang diperoleh.

\section{b. Metode Fuzzy Time Series Jasim}

Pada dasarnya metode ini memiliki kesamaan dengan Time Series Klasik, yang membedakan ada pada tahapan prediksinya. Perbedaan utama antara Fuzzy Time Series dengan traditional time series adalah nilai Fuzzy Time Series diwakili oleh himpunan fuzzy dimana $U=\left\{u_{1}, u_{2}, \ldots . ., u_{n}\right\}$. Definisi U sebagai Universe atau himpunan semesta (Jasim et al., 2012). Berikut langkah langkah berbasis pada Fuzzy Time Series Jasim ;

1. Membuat semesta himpunan $U$ dari data historis

2. Memastikan nilai tertinggi juga nilai terendah dari data, dimana D1 dan D2 adalah nilai acak yang digunakan untuk menentukan himpunan dari U (Universe of discourse $U$ ) sebagai berikut: $U=($ Dmin $-D 1$, Dmaks $+D 2)$

3. Menentukan panjang interval I dengan metode average based lenght sebagai berikut;

$$
a v=\frac{\sum_{i=1}^{a}\left(\left|x_{1}-x_{i-1}\right|\right)}{a-1}
$$

dimana $\mathrm{n}$ merupakan banyaknya data.

- Menghitung nilai tengah dengan menerapkan rumus $(l=a v / 2)$

- Menentukan jangkauan interval dari hasil B berdasarkan Tabel 1
Tabel 1. Pemetaan Basis Prediksi (Ekananta et al., 2018)

\begin{tabular}{cc}
\hline Range & Base \\
\hline $0.1-1$ & 0.1 \\
$1-10$ & 1 \\
$10-100$ & 10 \\
$100-1000$ & 100 \\
$1000-10000$ & 1000 \\
\hline
\end{tabular}

4. Menentukan jumlah interval fuzzy dengan menerapkan persamaan berikut :

$$
\left.m=x_{\text {maks }}+D 1-x_{\min }-D 2\right) / l
$$

5. Menentukan himpunan Fuzzy logical

6. Menentukan Fuzzy Logical Relation $A_{j}-A_{i}$

7. Menentukan hasil prediksi. Nilai prediksi waktu t ditentukan berdasarkan berikut:

a. Jika $A_{\mathrm{j}}$ adalah nilai kosong $A_{j} \rightarrow \emptyset$, berarti nilai $A_{v t}$ adalah nilai tengah dari interval $\mathrm{A}_{\mathrm{j}}$ dimana

$$
A_{j}=\left(d_{j-1}, d_{j}, d_{j+1}, d_{j+2}\right)
$$

b. Jika $A_{\mathrm{j}}$ adalah nilai anggota relasi one to one $A_{j} \rightarrow A_{k}$, berarti interval yang memiliki nilai prediksi adalah $A_{k}$. Untuk mendapatkan hasil prediksi langkah awal yang harus dilakukan adalah membandingkan nilai $\mathrm{j}$ dan $\mathrm{i}$ menggunakan persamaan berikut :

$$
Y=\left(x_{t}-x_{t-1}\right)-\left(x_{t-1}-x_{t-2}\right)
$$

Persamaan tersebut menggunakan ketentuan sebagai berikut,

1. Jika $j>i$, dan $Y>0$, maka kemungkinan prediksi akan naik dan menggunakan rule 2 untuk memprediksi.

2. Bila $j>i$ dan $Y<0$, maka kemungkinan prediksi turun dan menggunakan rule 3 untuk memprediksi.

3. Bila $j<i$ dan $Y>0$, maka kemungkinan prediksi naik dan menggunakan rule 2 untuk memprediksi.

4. Bila $j<i$ dan $Y<0$, maka kemungkinan prediksi naik dan menggunakan rule 3 untuk memprediksi.

5. Bila $j=i$ dan $Y>0$, maka kemungkinan prediksi naik dan menggunakan rule 2 untuk memprediksi.

6. Bila $j=i$ dan $Y<0$, maka kemungkinan prediksi turun dan menggunakan rule 3 untuk memprediksi.

Rule 1:

- Bila $z=\frac{\left|x_{t}-x_{t-1}\right|}{2}>\frac{A_{j}}{2}$, maka kemungkinan prediksi pada interval akan naik dan $F_{n}=0,75$ dari $A_{j}$.

- Bila $z=\frac{\left|x_{t}-x_{t-1}\right|}{2}=\frac{A_{j}}{2}$, maka kemungkinan prediksi adalah nilai tengah pada interval

- Bila $z=\frac{\left|x_{t}-x_{t-1}\right|}{2}<\frac{A_{j}}{2}$, maka kemungkinan prediksi pada interval akan turun dan $F_{n}=0,25$ dari $A_{j}$. 
Rule 2 :

- Bila z $=|\mathrm{Y}| * 2+X_{n-1} \in A_{j}$ atau $X_{n-1}-|\mathrm{Y}| *$ $2 \in A_{j}$, maka kemungkinan prediksi pada interval akan naik dan $F_{\mathrm{n}}=0,75$ dari $A_{\mathrm{j}}$

- Bila $\mathrm{z}=\frac{|\mathrm{Y}|}{2}+X_{t} \in A_{j} \quad$ atau $X_{n-1}-\frac{|\mathrm{Y}|}{2} \in A_{j}$, maka kemungkinan prediksi pada interval akan naik dan $F_{\mathrm{n}}=0,25$ dari $A_{\mathrm{j}}$

- Bila tidak keduanya, maka hasil prediksinya adalah nilai tengah dari interval $A_{j}$.

Rule 3 :

- Bila $\mathrm{z}=\frac{|\mathrm{Y}|}{2}+X_{t-1} \in A_{j}$ atau $z=X_{t-1}-\frac{|\mathrm{Y}|}{2} \in$ $A_{j}$, maka kemungkinan prediksi pada interval akan naik dan $F_{\mathrm{n}}=0,25$ dari $A_{\mathrm{j}}$

- Bila $\mathrm{z}=|\mathrm{Y}| * 2+X_{t-1} \in A_{j}$ atau $z=X_{t-1}-$ $|\mathrm{Y}| * 2 \in A_{j}$, maka kemungkinan prediksi pada interval akan naik dan $F_{\mathrm{n}}=0,75$ dari $A_{\mathrm{j}}$

- Bila tidak keduanya maka hasil prediksi merupakan nilai tengah interval $\mathrm{Aj}$.

c. Bila $A_{j}$ adalah one too many $A_{\mathrm{j}} \rightarrow A_{\mathrm{k} 1}, A_{\mathrm{k} 2}, \ldots \ldots$, $A_{\mathrm{kp}}$ maka hasil prediksi mengikuti ketentuan berikut ini :

- Bila selisih antara $\mathrm{K}_{1}, \mathrm{~K}_{2}, \ldots \ldots, \mathrm{K}_{\mathrm{p}} \leq 2$ maka nilai prediksinya merupakan nilai tengah dari interval tersebut.

- Bila selisih antara $\mathrm{K}_{1}, \mathrm{~K}_{2}, \ldots \ldots, \mathrm{K}_{\mathrm{p}}>2$ maka nilai prediksinya dihitung dengan mengunakan langkah ke 8 dengan ketentuan 2

\subsection{Alur Proses Perhitungan}

Proses perhitungan diilustrasikan dalam Gambar 1 dibawah ini.

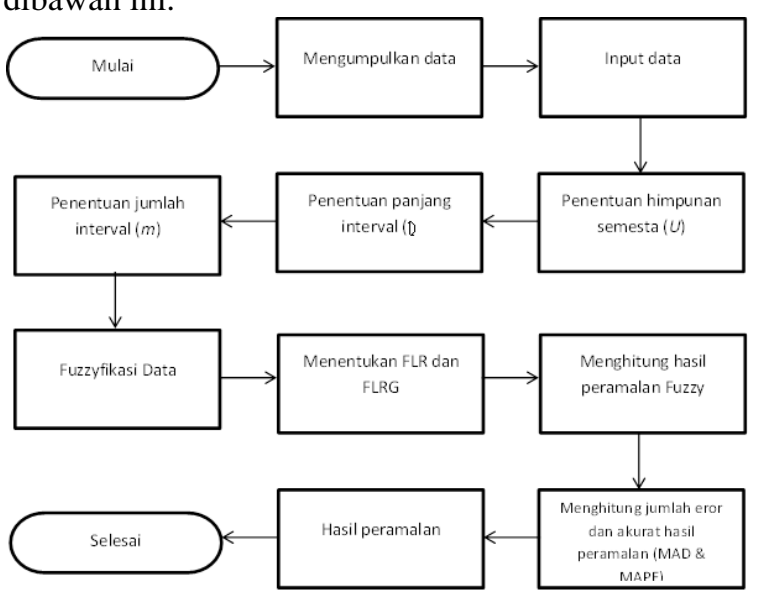

Gambar 1. Proses perhitungan pada fuzzy time series

\subsection{Mengukur Kesalahan Peramalan}

Sebuah peramalan tidak lah dapat dikatakan benar sepenuhnya, oleh karena itu dilakukannya perhitungan:

a. Mean Absolute Deviation (MAD)

MAD adalah metode untuk mengukur akurasi dari peramalan dengan membuat sama rata dari besarnya kesalahan perkiraan yang dimana setiap peramalan memiliki nilai absolut pada tiap errornya.

$$
M A D=\frac{1}{n} \sum_{t=1}^{n}\left|Y_{t}-X_{t}\right|
$$

$\mathrm{Y}_{\mathrm{t}}=$ nilai aktual (data sebenarnya) pada periode $t$

$\mathrm{X}_{\mathrm{t}}=$ nilai forecast pada periode $t$

\section{b. Mean Absolute Precentage Error (MAPE)}

MAPE guna melihat seberapa besar eror atau tidak sesuai pada hasil peramalan data aktual yang telah ada. MAPE merupakan rata-rata dari seluruh presentase kesalahan antara data aktual dengan hasil peramalan (Novita et al., 2019).

$$
\mathrm{MAPE}=\frac{\sum|A-F|}{\sum A} x 100 \%
$$

$\mathrm{A}=$ Data aktual

$\mathrm{F}=$ Hasil prediksi akhir

$\sum \mathrm{A}=$ Banyak data

\section{Metode}

Metodologi penelitian yang digunakan dalam beberapa fase ditampilkan pada Gambar 2 dibawah ini.

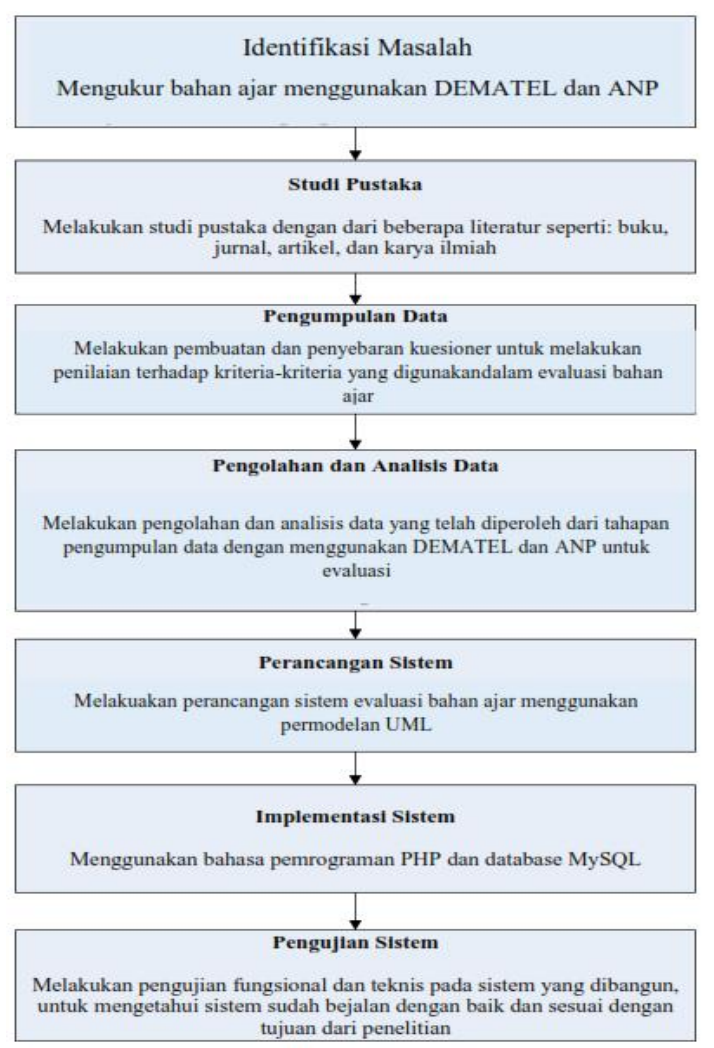

Gambar 2. Metodologi Penelitian

Penelitian yang dikembangkan ini merupakan penelitian kuantitatif. Tahapan Pendataan yang dilakukan dengan mengambil data dari laporan pasien covid di Indonesia dan dijadikan sebagai masukan dalam pengolahan sistem. Data yang Data yang digunakan adalah hasil monitoring pasien terinfeksi COVID pada Tabel 2. Kerangka kerja sistem yang dibangun menerapkan metode Fuzzy Time Series. 
Keluaran dari sistem ini digunakan sebagai rekomendasi untuk pengambilan keputusan peningkatan jumlah penderita covid.

\section{Hasil dan Pembahasan}

Pada penelitian ini menggunakan data dari perkembangan kasus COVID-19 di Indonesia dari minggu ke 12 pada tanggal 18 Mei 2020 hingga minggu ke 28 pada tanggal 13 September 2020. Data tersebut tertera pada Tabel 2 dibawah ini.

Tabel 2. Data Kasus COVID-19 di Indonesia

\begin{tabular}{cc}
\hline Minggu & Data Kasus \\
\hline 12 & 4757 \\
13 & 3641 \\
14 & 4713 \\
15 & 7092 \\
16 & 7614 \\
17 & 8119 \\
18 & 9739 \\
19 & 11950 \\
20 & 10714 \\
21 & 12066 \\
22 & 13714 \\
23 & 13965 \\
24 & 13815 \\
25 & 13986 \\
26 & 18518 \\
27 & 22056 \\
28 & 24273 \\
\hline &
\end{tabular}

Pada data diatas himpunan semesta menggunakan $\mathrm{U}=(3641-641,24273+27)$ sehingga didapatkan himpunan semesta $U=(3600,24300)$. Penelitian ini juga menggunakan algoritma average based length untuk menentukan panjang interval (1). Dari data diatas didapatkan rata rata selisih sebesar 1442,353. Dari rata rata selisih tersebut didapatkan interval (1) sebesar 721,1765 sehingga sesuai dengan Tabel 1 maka panjang interval dibulatkan dan di dapatkan basis sebesar 100 .

Setelah diketahui panjang interval maka dilakukan perhitungan $m=206,18$. lalu dilakukan pengelompokan Fuzzyfikasi Liguistik seperti pada tabel 3 dibawah ini.
Tabel 3. Fuzzyfikasi pada Data Kasus

\begin{tabular}{ccc}
\hline Minggu & Kasus Baru & Fuzzyfikasi \\
\hline 12 & 4757 & A12 \\
13 & 3641 & A1 \\
14 & 4713 & A11 \\
15 & 7092 & A35 \\
16 & 7614 & A40 \\
17 & 8119 & A45 \\
18 & 9739 & A61 \\
19 & 11950 & A84 \\
20 & 10714 & A71 \\
21 & 12066 & A84 \\
22 & 13714 & A101 \\
23 & 13965 & A103 \\
24 & 13815 & A102 \\
25 & 13986 & A103 \\
26 & 18518 & A148 \\
27 & 22056 & A183 \\
28 & 24273 & A205 \\
\hline & & \\
\hline
\end{tabular}

Dimana himpunan fuzzy menunjukkan nilai linguistik dari data kasus dan menetapkan hubungan logika fuzzy berdasarkan data sehingga dapat ditentukan FLR pada data. Setelah membentuk FLR (fuzzy logical relationship) didapatkan hasil peramalan (Forecast) dan MAPE pada tabel 4 berikut ini.

Tabel 4. Hasil Forecasting

\begin{tabular}{ccc}
\hline Minggu & Kasus Baru & Forecasting \\
\hline 12 & 4757 & 0 \\
13 & 3641 & 3650 \\
14 & 4713 & 4660 \\
15 & 7092 & 7084 \\
16 & 7614 & 7589 \\
17 & 8119 & 8094 \\
18 & 9739 & 9710 \\
19 & 11950 & 12033 \\
20 & 10714 & 10720 \\
21 & 12066 & 12033 \\
22 & 13714 & 13750 \\
23 & 13965 & 13952 \\
24 & 13815 & 13851 \\
25 & 13986 & 13952 \\
26 & 18518 & 18497 \\
27 & 22056 & 22032 \\
28 & 24273 & 24254 \\
\hline & MAPE & $2.43 \%$ \\
\hline
\end{tabular}


Setelah didapatkan hasil forecasting dari data aktual. Maka selanjutnya adalah menghitung nilai MAPE untuk mengetahui presentasi penyimpangan hasil peramalan dan didapatkan nilai sebessar $2.43 \%$ dan MAD sebesar 286. Dalam penggunaan forecasting ini metode Fuzzy Time Series Jasim dinilai sangat baik.

\section{Kesimpulan}

Dari data yang digunakan untuk penulisan ini yang merupakan data kasus COVID-19 di indonesia pada tiap minggunya selama 14 minggu terhitung dari bulan Mei hingga 13 September 2020. Dari tabel 4 dapat diketahui bahwa metode Fuzzy Time Series Jasim menyajikan hasil peramalan dengan baik. Dari hasil perhitungan MAPE juga didapatkan hasil $2.43 \%$ yang dapat dikatakan sangat baik dengan presentasi kecil penyimpangan hasil peramalan dan rata rata kesalahan sebesar 286

\section{Daftar Pustaka}

Abd, F., Jalil, S.K., 2019. Meningkatnya angka pengangguran ditengah pandemi (COVID-19). AlMizan : Jurnal Ekonomi Syariah.

Indriyanti, A.D., Prehanto, D.R., Permadi, G.S., Mashuri, C. and Vitadiar, T.Z., 2019. Using fuzzy time series (FTS) and linear programming for production planning and planting pattern scheduling red onion. The 4th International Conference on Energy, Environment, Epidemiology and Information System (ICENIS 2019).

Prehanto, D.R., Indriyanti, A.D., Mashuri, C. and Permadi, G.S., 2019. Soil moisture prediction using fuzzy time series and moisture sensor technology on shallot farming. The 4th International Conference on Energy, Environment, Epidemiology and Information System (ICENIS 2019).

Permadi, G.S., Vitadiar, T.Z., Kistofer, T. and Mujianto, A.H., 2019. The Decision Making Trial and Evaluation Laboratory (Dematel) and Analytic Network Process (ANP) for Learning Material Evaluation System in E3S. Web of Conferences.
Permadi, G.S., Vitadiar, T.Z. and Kistofer, T., 2019. Sistem evaluasi bahan pembelajaran menggunakan metode DEMATEL dan ANP. J. Sist. Inf. BISNIS, 9(2): 228-235.

Jasim, H.T., Salim, A.G.J., Ibraheem, K.I., 2012. A novel algorithm to forecast enrollment. Applications and Applied Mathematics: An International Journal (AAM): 386-397.

Sucipto, L., dan Syaharuddin, S., 2018. Konstruksi forecasting system multi-model untuk pemodelan matematika pada peramalan indeks pembangunan manusia Provinsi Nusa Tenggara Barat. Jurnal Ilmiah Teknologi Sistem Informasi, 116-117.

Novita, Bettiza, M., Uperiati, A., 2019. Perbandingan tingkat akurasi metode fuzzy time series model markov chain dan metode Fuzzy Time Series Jasim untuk memprediksi jumlah penumpang kapal. Studi kasus: Pelabuhan Sri Bintan Pura dalam Negeri. Skripsi, UMRAH.

Pratikto, F.R., 2020. Prediksi Akhir Pandemi COVID19 di Indonesia dengan Simulasi. J. Rekayasa Sistem Industri, (9) 2: 63-68.

Sudarsono, A., 2016. Jaringan syaraf tiruan untuk memprediksi laju pertumbuhan penduduk menggunakan metode Backpropagation studi kasus di Kota Bengkulu. J. Media Informasi: 6169.

Tanhella, Z.V., Permadi, G.S., 2017. Sistem Informasi penentuan jumlah produksi jamur tiram menggunakan Metode Fuzzy Inference System (Fis) Tsukamoto. INOVATE (2)1: 11-16.

Yulian, E., Muflikhah, L., Dewi, C., 2018. Penerapan Metode Average-Based Fuzzy Time Series untuk prediksi konsumsi energi listrik Indonesia. Jurnal Pengembangan Teknologi Informasi dan Ilmu Komputer, (2)3 : 1283-1289.

Agus, P.W., 2020. Jaringan Saraf Tiruan : Algoritma Prediksi dan Implementasi. Yayasan Kita Menulis.

Douglas, C., Montgomery, C.L., Jennings, Kulahci, M., 2016. Introduction to Time Series Analysis and Forecasting. New Jersey: John Wiley \& Sons, Inc.

Peter, J., Brockwell, Davis, R.A., 2002. Introduction to Time Series and Forecasting. New York, USA: Springer Science+Business Media, LLC.

Winarno, F., 2020. Covid-19 : Pelajaran Berharga dari Sebuah Pandemi. Jakarta: PT Gramedia Pustaka Utama. 